\title{
Front Matter: Volume 6755
}

, "Front Matter: Volume 6755," Proc. SPIE 6755, Advanced Environmental, Chemical, and Biological Sensing Technologies V, 675501 (8 October 2007); doi: $10.1117 / 12.776918$

SPIE. Event: Optics East, 2007, Boston, MA, United States 


\title{
PROCEEDINGS OF SPIE
}

\section{Advanced Environmental, Chemical, and Biological Sensing Technologies $V$}

\author{
Tuan Vo-Dinh \\ Robert A. Lieberman \\ Günter Gauglitz \\ Editors \\ 10-11 September 2007 \\ Boston, Massachusetts, USA \\ Sponsored and Published by \\ SPIE
}

Volume 6755 
The papers included in this volume were part of the technical conference cited on the cover and title page. Papers were selected and subject to review by the editors and conference program committee. Some conference presentations may not be available for publication. The papers published in these proceedings reflect the work and thoughts of the authors and are published herein as submitted. The publisher is not responsible for the validity of the information or for any outcomes resulting from reliance thereon.

Please use the following format to cite material from this book:

Author(s), "Title of Paper," in Advanced Environmental, Chemical, and Biological Sensing Technologies V, edited by Tuan Vo-Dinh, Robert A. Lieberman, Günter Gauglitz, Proceedings of SPIE Vol. 6755 (SPIE, Bellingham, WA, 2007) Article CID Number.

ISSN 0277-786X

ISBN 9780819469151

Published by

SPIE

P.O. Box 10, Bellingham, Washington 98227-0010 USA

Telephone +1 3606763290 (Pacific Time) · Fax +1 3606471445

SPIE.org

Copyright (C) 2007, Society of Photo-Optical Instrumentation Engineers

Copying of material in this book for internal or personal use, or for the internal or personal use of specific clients, beyond the fair use provisions granted by the U.S. Copyright Law is authorized by SPIE subject to payment of copying fees. The Transactional Reporting Service base fee for this volume is $\$ 18.00$ per article (or portion thereof), which should be paid directly to the Copyright Clearance Center (CCC), 222 Rosewood Drive, Danvers, MA 01923. Payment may also be made electronically through CCC Online at copyright.com. Other copying for republication, resale, advertising or promotion, or any form of systematic or multiple reproduction of any material in this book is prohibited except with permission in writing from the publisher. The CCC fee code is 0277-786X/07/ $\$ 18.00$.

Printed in the United States of America.

Publication of record for individual papers is online in the SPIE Digital Library.

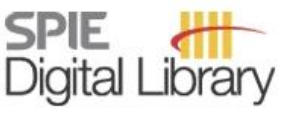

SPIEDigitalLibrary.org

Paper Numbering: Proceedings of SPIE follow an e-First publication model, with papers published first online and then in print and on CD-ROM. Papers are published as they are submitted and meet publication criteria. A unique, consistent, permanent citation identifier (CID) number is assigned to each article at the time of the first publication. Utilization of CIDs allows articles to be fully citable as soon they are published online, and connects the same identifier to all online, print, and electronic versions of the publication. SPIE uses a six-digit CID article numbering system in which:

- The first four digits correspond to the SPIE volume number.

- The last two digits indicate publication order within the volume using a Base 36 numbering system employing both numerals and letters. These two-number sets start with 00, 01, 02, 03, 04, 05 , $06,07,08,09,0 A, O B \ldots$. OZ, followed by 10-1Z, 20-2Z, etc.

The CID number appears on each page of the manuscript. The complete citation is used on the first page, and an abbreviated version on subsequent pages. Numbers in the index correspond to the last two digits of the six-digit CID number. 


\section{Contents}

$\checkmark$ Conference Committee

\section{SESSION 1 CHEMICAL SENSING}

675502 Remote gas sensing with long wavelength DFB laser diodes [6755-03]

J. Koeth, M. Fischer, M. Legge, J. Seufert, R. Werner, nanoplus Nanosystems and Technologies GmbH (Germany)

675503 Polymer waveguide sensor arrays for enhanced multichemical detection [6755-01]

S. R. Cordero, A. Low, D. Ruiz, R. A. Lieberman, Intelligent Optical Systems (USA)

675504 A wireless sensor network for methane monitoring [6755-02]

J. Hayes, C. Slater, B. Kiernan, C. Dunphy, W. Guo, K.-T. Lau, D. Diamond, Dublin City Univ. (Ireland)

675505 Simple and sensitive protein detection system using UV LEDs and liquid core waveguides [6755-05]

M. Belz, World Precision Instruments, Inc. (USA)

\section{SESSION 2 PHYSICAL SENSING}

675507 A fiber optic sensor for simultaneous temperature and saccharinity measurement [6755-07] P. LU, Q. Chen, Memorial Univ. of Newfoundland (Canada)

$675508 \quad$ New-generation security network with synergistic IP sensors [6755-34]

I. Peshko, Univ. of Toronto at Mississauga (Canada)

675509 Applications of rare-earth ion-doped crystals for temperature measurement [6755-09] P. Kommidi, I. Kamma, B. R. Reddy, Alabama A\&M Univ. (USA)

6755 OB Hyperspectral imaging based procedures applied to bottom ash characterization [6755-11]

G. Bonifazi, S. Serranti, Sapienza, Univ. di Roma (Italy)

\section{SESSION 3 BIOLOGICAL SENSING}

6755 OE Full-field optical coherence tomography (OCT) and early alterations in chloroplast morphology [6755-14]

A. C. Boccara, ESPCI/UPMC, CNRS (France); R. De Paepe, Univ. Paris-Sud, CNRS (France);

A. Dubois, ESPCI/UPMC, CNRS (France); M. Boccara, Univ. Pierre et Marie Curie (France) 
$6755 \mathrm{OH}$ Tracking SERS-active nanoprobe intracellular uptake for chemical and biological sensing [6755-33]

M. K. Gregas, F. Yan, J. Scaffidi, H.-N. Wang, C. Khoury, Y. Zhang, T. Vo-Dinh, Duke Univ. (USA)

\section{SESSION 4 ENVIRONMENTAL SENSING I}

6755 0J Continuous spectral measurement of backscattering in sea water [6755-19]

J. Zhou, A. Gilerson, I. Ioannou, B. Gross, F. Moshary, S. Ahmed, City College/CUNY (USA)

$6755 \mathrm{OL}$ Autonomous field-deployable device for the measurement of phosphate in natural water [6755-21]

C. Slater, J. Cleary, C. M. McGraw, Dublin City Univ. (Ireland); W. S. Yerazunis, Mitsubishi Electric Research Labs. (USA); K.-T. Lau, D. Diamond, Dublin City Univ. (Ireland)

\section{SESSION 5 ENVIRONMENTAL SENSING II}

6755 OP Detection of nitrite by flow injection analysis using a novel paired emitter-detector diode (PEDD) as a photometric detector [6755-04]

M. O'Toole, R. Shepherd, K.-T. Lau, D. Diamond, Dublin City Univ. (Ireland)

\section{SESSION 6 SENSOR COMPONENTS AND TECHNIQUES}

6755 OS VAPI: low-cost rapid automated visual inspection system for Petri plate analysis [6755-27]

L. T. Chatburn, B. C. Kirkup, M. F. Polz, Massachusetts Institute of Technology (USA)

6755 OV A smart cap for olive oil rancidity detection using optochemical sensors [6755-31]

A. G. Mignani, L. Ciaccheri, A. A. Mencaglia, CNR-IFAC (Italy); R. Paolesse, M. Mastroianni, D. Monti, Univ. di Roma Tor Vergata (Italy); G. Buonocore, CNR-IMCB (Italy); A. Del Nobile,

A. Mentana, M. F. Grimaldi, Univ. di Foggia (Italy)

\section{POSTER SESSION}

6755 OW Development and testing of a multiwell plates absorbance reader for clinical analysis using inexpensive webcam [6755-17]

J. Castillo, H. Gutierrez, Y. Vitta, M. Martinez, A. Fernandez, Escuela de Química Facultad de Ciencias (Venezuela)

$67550 X$ Bio-sensing based on plasmon-coupling caused by rotated sub-micrometer gratings in metal-dielectric interfacial layers [6755-32]

M. Csete, Á. Sipos, A. Szalai, A. Mathesz, Univ. of Szeged (Hungary); M. A. Deli, Sz. Veszelka, Institute of Biophysics (Hungary); A. Schmatulla, Univ. of Ulm (Germany); A. Kőházi-Kis, K. Osvay, Univ. of Szeged (Hungary); O. Marti, Univ. of Ulm (Germany); Zs. Bor, Univ. of Szeged (Hungary)

Author Index 


\title{
Conference Committee
}

\author{
Symposium Chairs
}

Tuan Vo-Dinh, Duke University (USA)

Robert A. Lieberman, Intelligent Optical Systems, Inc. (USA)

Conference Chairs

Tuan Vo-Dinh, Duke University (USA)

Robert A. Lieberman, Intelligent Optical Systems, Inc. (USA)

Günter Gauglitz, Universität Tübingen (Germany)

Program Committee

Francesco Baldini, Istituto di Fisica Applicata Nello Carrara (Italy)

Stephanus Buettgenbach, Technische Universität Braunschweig (Germany)

Luigi Campanella, Università degli Studi di Roma, La Sapienza (Italy)

Masoud Ghandehari, Polytechnic University (USA)

Fabien J. Josse, Marquette University (USA)

Lothar U. Kempen, Intelligent Optical Systems, Inc. (USA)

Robert Lascola, Savannah River National Laboratory (USA)

Marco Leona, The Metropolitan Museum of Art (USA)

Anna G. Mignani, Istituto di Fisica Applicata Nello Carrara (Italy)

Klaus Schäfer, Forschungszentrum Karlsruhe GmbH (Germany)

Khalid J. Siddiqui, SUNY Fredonia (USA)

Jagdish Prasad Singh, Mississippi State University (USA)

David L. Stokes, EOIR Technologies, Inc. (USA)

Eiichi Tamiya, Japan Advanced Institute of Science and Technology (Japan)

Irena Twardowska, Polska Akademia Nauk (Poland)

\section{Session Chairs}

1 Chemical Sensing

Robert A. Lieberman, Intelligent Optical Systems, Inc. (USA)

2 Physical Sensing

Anna G. Mignani, Istituto di Fisica Applicata Nello Carrara (Italy)

3 Biological Sensing

Tuan Vo-Dinh, Duke University (USA) 
4 Environmental Sensing I

Günter Gauglitz, Universität Tübingen (Germany)

Claude Boccara, Centre National de la Recherche Scientifique (France)

5 Environmental Sensing II

Günter Gauglitz, Universität Tübingen (Germany)

Anna G. Mignani, Istituto di Fisica Applicata Nello Carrara (Italy)

6 Sensor Components and Techniques

Lothar U. Kempen, Intelligent Optical Systems, Inc. (USA) 